\title{
‘Am I not an author?’: Social Class \& the Contemporary French Novel
}

\section{Helena Chadderton}

This is an Accepted Manuscript of an article published by Taylor \& Francis in Modern and Contemporary France on 21 September 2018, available online:

http://www.tandfonline.com/10.1080/09639489.2018.1518319.

\begin{abstract}
While the term 'working-class' has fallen out of usage as the concept of class has lost its visibility and its power as a métarécit, this does not mean the issues that this term evokes have gone away. The hardship that comes of particular working lives, as well as the values and culture which are distinct from dominant bourgeois values, still exist. Indeed in a France and a Europe in which inequality is growing, and in which 'précarité' has become an everyday term, how is this reality represented in the contemporary French novel? Through a discussion of the relationships between class, society and literature, this article will explore the tensions between the literary world and the working-class novel. It will then turn to the work of contemporary writers Olivier Adam and Edouard Louis, who not only engage with issues of social class in their creative work, but equally condemn the disconnect between literature and society on the French literary scene. This article will show that the workingclass experience has potentially been side-lined as a result not only of the reduction in visibility of the very idea of social class but also as a result of the French literary scene’s approach to literature.
\end{abstract}

Keywords: working-class, society, social, novel, literary scene, Olivier Adam, Edouard Louis 
The 2007 'Pour une littérature monde’ manifesto laudably attempted to deracialise the French literary scene by disputing the label 'francophone' when applied to writers from outside l'Hexagone (Le Bris and Rouaud, 2007a and 2007b). However, Alec G. Hargreaves remarks on the fact that the creators of the 'littérature monde' manifesto did not invite any 'beur' or 'banlieue' authors to sign its call for increased plurality (2014). Indeed, while the very purpose of the manifesto was to break down the barriers between literature labelled 'française' and 'francophone', evidently a further barrier exists. This barrier is one of social class. In 2018 the term 'class’ has lost its power as a métarécit, collective working identity has been gradually eroded and we have seen the rise (and indeed normalisation) of neoliberalism, but this does not mean the issues that this term evokes have gone away. ${ }^{1}$ Indeed, in France and across Europe inequality is growing, we are seeing the rise of nationalist populism and 'précarité' has become an everyday term. As such, this article purports to examine the relationship between this social reality and the contemporary literary scene. In so doing I will show that social problems, and specifically, issues of class, have been side-lined in literature as a result not only of the reduction in visibility of the very idea of social class, but also as a result of the French literary scene’s approach to literature.

The interest surrounding the publication of Edouard Louis's first and best-selling 'novel', En finir avec Eddy Bellegueule (Seuil, 2014), and in particular the comments the author has made in the Anglophone press, have revived arguments about class and the contemporary French literary scene. In an interview for The Guardian on the publication of its English translation, The End of Eddy, ${ }^{2}$ he made the following comment: 'My books are born out of an absence: I began writing because I could not find the world of my childhood anywhere in books' (2017a). The 'world of his childhood' is poor, rural, and uneducated. This declaration

\footnotetext{
${ }^{1}$ Sociologists such as Robert Castel and Alain Touraine have shown us that the constitution of the working class has changed: Castel 1995, Touraine, 1992.

${ }^{2}$ Translated by Michel Lucey and published by Harvill Secker in 2017.
} 
of the invisibility of working-class life in contemporary French novels has been made elsewhere, notably by Joseph Macé-Scaron, former director of Le Magazine Littéraire in France, who in 2012 claimed that: 'le peuple' are 'ce grand oublié' in French contemporary literature (Macé-Scaron). Similarly, comparing Anglophone and French literature, critic Laurent Wolf made a similar point in Le Temps:

Aujourd'hui, il existe un extraordinaire écart entre la manière dont les écrivains anglosaxons et les écrivains français inscrivent la littérature dans l'espace des événements et dans l'espace matériel. Dans l'un, chacun peut se reconnaître. Dans l'autre, chacun voit bien, le plus souvent, qu'il ne lui appartient pas et qu’il n'est pas concerné par lui (Wolf 2006). ${ }^{3}$

This sense that the contemporary French novel does not draw on the lives of 'ordinary people', but rather on the lives of a Parisian elite, is something that the author Olivier Adam has been saying both in and outside his creative work for some years. In their attacks on French literary culture, Adam and Louis are echoing one of the charges that has been levelled against the French contemporary novel in recent years: that it neglects the social and political world in favour of individual, psychological or abstract preoccupations (Domenach 1995; Jourde 2002; Todorov 2007). The significance of Adam's and Louis’s interventions lies partly in the fact that they link this development to the concept of class.

Contemporary authors whose work engages with the experience of the contemporary working-class include François Bon, Marie-Hélène Lafon and Lydie Salvayre. A great deal of critical attention has been paid to the work of François Bon, largely focusing on the relationship between realism and reality in his writing (Asholt, Chadderton 2017a,Viart and Vrey). While Bon always focuses on those on the margins of society (examples include the

\footnotetext{
${ }^{3}$ William Cloonan also makes a similar point about US literature in Cloonan 2008.
} 
experience of prison, the difficulty of reintegrating into society, unemployment, manual work), his experimental style constantly brings into question the relationship between the world and the text. While aesthetic issues are evoked by Adam's and Louis’s work, largely surrounding the association between author, narrator and protagonist (Lalanne; TremblayCleroux), their work is powerful precisely because of their use of social realism and their openly political approach to their subject. Following a discussion of the relationship between class and literature, I will turn to the fictional and discursive work of Adam and Louis to show how they challenge the status quo of the champ littéraire and make visible a demand for a specific type of literary fiction which excludes the working-class experience.

In recent years, commentators and critics of the French novel have frequently proclaimed a return to 'the real', to 'the story', to social, political and historical subjects in the contemporary French novel (Davis and Fallaize 2000; Viart and Vercier 2005; Kemp 2010). As Wolfgang Asholt and Marc Dambre remind us in the introduction to their 2011 study, 'le fait que la littérature et plus spécialement le roman se tournent de nouveau vers le monde est devenu le paradigme dominant des études actuelles’ (2011, 12-13). Be that as it may, they go on to make the point that 'on ne pratique plus souvent une vue d'ensemble et on la situe encore moins dans le contexte d'une idéologie' (ibid). Indeed, among these various 'returns', reconnection with the social and political is arguably the most problematic aspect of this tendency, since traditionally in the French context the gulf between literature on one side, and society and politics on the other, has been wide, as Edouard Louis reminded a US audience in The Paris Review in 2016: 'In France, there’s been this ideal for a long time now of moving literature as far away from political realities as possible. For most writers, to intervene in politics would constitute a violation of the purity of literature’ (Farsethås 2016).

While France may have a robust history of writers involving themselves in public debate, with the Zola affair being the most well-known example of this, there is nonetheless a 
dominant current of thinking which dismisses the link between literature and the social and political. Indeed, even at the time at which Zola was writing, the view that art should be independent of political ideas, that it should function according to its own laws and fulfil a need of its own is encapsulated in a statement by the Goncourt brothers, that: 'l'artiste, l'homme de lettres, le savant, ne devraient jamais se mêler de politique: c'est l'orage qu'ils devraient laisser passer au-dessus d'eux' (Caramaschi 1971, 96). ${ }^{4}$ That the autonomy of literature is sacred, and that the writer should represent 'universal' values, are ideas which quietly but firmly provide the pillars for the French literary scene. The French reader, according to Stéphane Giocanti, is seeking a neutral truth from his or her literature (2009, 292), something that Gisèle Sapiro calls 'the independence of aesthetic judgment' (2003, 642). Dominique Viart expresses the widely-held belief that literature should be: 'enfin et effectivement lu pour lui-même; en lui-même, indépendamment de toutes considérations externes, qui auraient pu en borner l’enjeu ou en réduire le(s) sens’ (Viart 2007, 11).

The particularity of literature, its separateness from the world, its capacity to be universal, were all brought into question by Bourdieu's approach, whose work on the champ littéraire problematised the idea of 'lecture pure'. Indeed, as Jean-Pierre Martin describes, Bourdieu aimed to: 'dénuder tous les mots qui font oublier la condition sociale et matérielle de la Littérature’, which left the literary world reeling (Martin 2010, 11). Bourdieu shows that literature is always socially and politically positioned; that while we may have lived through the period of 'the death of the author' and the text is certainly to be read on its own terms with its multiple significations, writers still have to eat, and publishers make choices based on social and political norms. As his La distinction shows us : 'l'art et la consommation artistique sont prédisposés à remplir, qu’on le veuille ou non, qu’on sache ou non, une fonction sociale de légitimation des différences sociales’ (1979, VIII). While praising

\footnotetext{
${ }^{4}$ See the introduction of Chadderton and Kimyongür 2017, 1-9, for more details on the development of littérature engagée.
} 
structuralism for placing literary texts within what he calls 'le système des œuvres', Bourdieu nonetheless claims that the structuralists 'ont ignoré, tacitement ou explicitement...le système des gens qui produisent les œuvres, ce petit monde social à l’intérieur du monde social, que j'appelle le champ...' (1992). ${ }^{5}$

Furthermore, the questioning of the relationship between the sign and the world, so prevalent in France from the 1950s onwards, most famously in the form of structuralism and then poststructuralism, and in the practices and theory of the nouveau roman, meant that writing literature which brings language and the world together unproblematically was seen to be at best, naive, and at worst, impossible. Having produced realist novelists par excellence in the $19^{\text {th }}$ century: Balzac and Zola, the dominant literary aesthetic of twentieth century France ploughed a very different furrow. The French anti-realist tradition not only came to perceive of a lack of skill in mimetic representation, but also problematised the very concept of 'the real', leading to an undervaluing of both the result of, and the attempt at, the recreation of reality (Walker 1997, 126-44). Indeed, while texts at this time aimed to be revolutionary, their political content came to be increasingly overlooked in favour of their experimental form, as Barthes claimed: 'La Forme est la première et dernière instance de la responsabilité littéraire’ $(1953,64)$.

Clearly, for a novel purporting to relate contemporary working-class life, the relationship between the world and the text remains highly significant. Further, that it should be free of political ideas is problematic given that the very presence of this world in literary space is often used to draw attention to social inequalities. Michel Ragon insists that (what he calls) 'la littérature ouvrière’ must be : ‘témoignage direct...ce qui pouvait montrer le visage authentique du peuple, son évolution, ses aspirations, ses plaintes et ses joies’ $(1974,19)$. This description in fact recalls the practices of documentary, representing literature as a

\footnotetext{
${ }^{5}$ More recently, see also Dumas 2002, 260.
} 
means of recording sociological information. If perceived in this way, 'la littérature ouvrière' directly feeds fears in the literary world pertaining to simplistic assumptions about the relation between the real and the text as well as the potential instrumentalisation of literature.

France has a rich history of what has been labelled 'littérature prolétarienne', catalogued most significantly by Henry Poulaille and Michel Ragon (Ragon 1974; Not and Radwan 2003). Some of the most well-known literary accounts of working-class life published today are those which cast a nostalgic look backwards, such as Aurélie Filipetti’s Les derniers jours de la classe ouvrière (2003) and Frank Magloire’s Ouvrière (2012), both of which recall the authors’ parents’ experiences as factory workers. Significantly, Roselyne Waller suggests that Filipetti's text was well-received by the mainstream media precisely because of its title: 'si elle se meurt, la classe laborieuse ne peut plus être dangereuse...' (2010, 89). More contemporary is the genre commonly known as 'la fiction d'affaires', concerned with fiction to do with business or the workplace, and often a critique of the neo-liberal workplace. ${ }^{6}$ Critic Jacques Mandelbaum suggests that 'le monde du travail semble devenir la plate-forme d’observation privilégiée des grandes mutations sociales et économiques’ (2007). Be that as it may, Thierry Beinstingel, author of a number of texts about work, questions how happily literature and work sit together in the French context, given existing attitudes: 'rares sont les écrivains qui se risquent...au thème du travail comme si le roman, l’art de fabriquer des fictions les tenaient éloignés de toute tentative de restitution de la vie la plus prosaïque et laborieuse' (2012). ${ }^{7}$ Equally, following a Europe-wide trend, the roman noir in France has taken on the role of representing the evils of society. ${ }^{8}$ Indeed, crime writer Dominique Manotti has called le roman noir 'le roman du 21è siècle', because 'le crime est constitutif de

\footnotetext{
${ }^{6}$ See, for example, the work of Thierry Beinstingel or Delphine de Vigan. This is a flourishing area of critical attention. See, for example, Chadderton 2017b.

${ }^{7}$ For a more in-depth discussion of Beinstingel's work and views on la fiction d'affaires, see also Chadderton, 2017.

${ }^{8}$ See Hynyen 2017 for a breakdown of the definitions often used interchangeably in this area.
} 
la société et fait partie du maintien de l'ordre' (2014). Didier Daeninckx, writer of romans policiers with a socially critical message, makes the point that the success and flourishing of the roman noir in the 1970s and 80s in France was potentially a result of writers with a social interest taking refuge within it, as the novel itself became too strict in its parameters: 'Lassés par un nouveau roman tournant à la vieille lune, dégoûtés par les théoricistes telquelliens proclamant la mort du roman pour mieux y établir leurs petites affaires le temps venu, quelques dizaines de petits soldats du noir se sont engouffrés dans la brèche ouverte par JeanPatrick Manchette’ (Daeninckx 1997, 137). ${ }^{9}$ According to Daeninckx, then, writers who wanted to continue to explore the relationship between literature and society found a welcoming home in the roman noir, rejected as they felt by literary fiction. Recent academic study on a further literary genre has traced the semantic movement from 'littérature beur' to 'littérature de banlieue', noting that while its subject has stayed similar - the search for identity in a Republic in which one is not recognised - the identities of its authors have perhaps diversified, representing, as Alec Hargreaves notes 'principalement...des minorités post-coloniales' (2014), rather than exclusively 'beur’ voices, as was previously the case. ${ }^{10}$ The pivotal moment at which the qualifier used in publishing and in the press changed from 'beur' to 'de banlieue' seems to have been following the 2005 riots, when there was a huge increase in the number of manuscripts submitted 'from the banlieues' (Hargreaves 2013, 224). As mentioned in the introduction, in the widely mediatised attempt to deracialise the French literary scene, the issue of social class and its relationship with race was not addressed. Indeed, what seems to be of interest to the literary scene is not the deprivation described in 'la littérature de banlieue’, but rather its ‘extraordinarily rich and dynamic cultural diversity’ (Hargreaves 2013, 212). This tendency for literature which deals with working-class issues to be categorised as genre fiction indicates that this literature is

\footnotetext{
${ }^{9}$ Manchette was a leading French crime writer who wrote from a left-wing perspective.

${ }^{10}$ See Pobel 2003 which compares la littérature beur to la littérature prolétarienne of the past.
} 
exceptional in some way, that it exists outside the established literary norms which, as we have seen, are required to be universally resonant (Dumas 2002, 261). Notably, the literary fiction of Olivier Adam and Edouard Louis does not fit into the categories of 'littérature de banlieue', or 'fiction d'affaires', thus making their difference all the more conspicuous. Indeed what we will now see is that what is perceived to be universal is in fact remarkably specific and stubbornly blind to the working-class experience.

\section{Olivier Adam: 'auteur social'}

Olivier Adam has sown disorder in the establishment. Born in 1974, he has shown himself to be extremely prolific in a way that contemporary French authors often are, producing nine novels and one prize-winning collection of short stories since $2001 .{ }^{11}$ Adam’s works are infamously dark, treating the deaths of close family members (often including suicide), disappearance, alcoholism, eating disorders and the relationships between estranged family members, sometimes all in the same novel.

Echoing Annie Ernaux’s situation of having 'le cul entre deux chaises’ $(1974,181),{ }^{12}$ Adam expresses in his work and indeed purports to experience in his everyday life 'un conflit de classes’ (Busnel 2012), having moved from, in his own words, 'un milieu très populaire’, to ‘le milieu littéraire parisien’, and has described the tension of wanting to escape the world he grew up in, while simultaneously making it the subject of his work (Busnel 2012). Touted each year as a contender for the Goncourt, ${ }^{13}$ Adam has nonetheless never won the most illustrious of France’s many literary prizes, leading some to mutter darkly about elitism, none

\footnotetext{
${ }^{11}$ Adam has also written for children and written a number of screen-plays which will not be discussed here due to their different intended audience or genre. His novels to date are : Je vais bien, ne t'en fais pas (2000, Le Dillettante) ; À l'Ouest (2001, Editions de l'Olivier) ; Poids léger (2002, l’Olivier) ; Passer l'hiver (2004, l'Olivier) - Goncourt de la nouvelle ; Falaises (2005, l'Olivier) ; A l'abri de rien (2007, l'Olivier) ; Des vents contraires (2009, l’Olivier) ; Le cœur régulier (2010, l’Olivier) ; Les lisières (2012, Flammarion) ; Peine perdue (2014, Flammarion), La renverse (2016, Flammarion).

${ }^{12}$ The writer expresses affinity with Ernaux in his interview with Busnel (2012).

${ }^{13}$ Adam won the Goncourt de la nouvelle in 2004 for Passer l'hiver.
} 
more so than Adam himself: ‘Je sais qui est dans le jury, et je n’en connais quasiment aucun dont je sais qu'il apprécie mon travail. Frédéric Beigbeder, par exemple, ne m’aime pas. Je n’ai aucun ami parmi les critiques littéraires...' (De Sepausy 2014). ${ }^{14}$ Certainly, Adam’s stinging attacks on hierarchy in French social and cultural systems, as well as specifically in the literary scene, both in his creative work and in the media, make him the natural enemy of the French literary scene.

Adam has made his specialism the evocation of 'la vie du lotissement' (Adam 2001, 14), setting his novels again and again in a Parisian banlieue devoid of charm and culture, providing merely functional places of residence and work. ${ }^{15}$ In each novel he lists the familiar suburban scene, a world defined by function, and often by commercialism, this intratextuality merely serving to underline his point about its ubiquity, while the detail of the state of infrastructure recalls Zola:

toute cette géographie indistincte et commune, qui ne signifie rien pour ceux qui n’y ont pas vécu. La gare RER et la maison de jeunesse, l’hôpital et l’Intermarché, le parking et les pelouses trouées de la cité Youri-Gagarine, le bar PMU, l’ANPE, le cinéma, la cour de l'école et les traits de craie sur les façades...etc... $(2005,30)$

Adam depicts working-class families, or, as he describes them 'classes populaires' (Adam 2013), without nostalgia or rose-tinted glasses, frequently defining their worlds through the listing of concrete examples :

les bonnes femmes... avec leurs caddies remplis jusqu'à la gueule, bourrés de lessive, de papier-toilette, de viande à congeler, de pâtes et de sucreries pour les enfants, de

\footnotetext{
${ }^{14}$ See also Raynal 2014.

${ }^{15}$ Marie-Ève Tremblay-Cléroux comments that la banlieue in Les lisières 'prend l'apparence d'une antithèse de Paris' (2014, 37).
} 
produits ménagers, de sucre, des beurre et de farine, de détergents, de chaussettes par lots de quatre paires...(2005, 96)

Social connotations are gathered in this way, from the cigarette brand smoked to the TV programmes watched. On his rare sorties to other parts of Paris, his protagonist feels out of place, with the middle-class Parisian youth feeling like a different species:

Autour de nous, c'était des grappes de lycéens, d'étudiants qui ne nous ressemblaient pas, et paraissaient appartenir à une autre espèce, une espèce protégée. Ils portaient des vestes de velours, des foulards et les cheveux mi-longs, les garçons comme les filles. Leurs manières étaient élégantes, ils fumaient avec affectation, riaient sans vulgarité, parlaient musique, cinéma, littérature. Mon frère et moi, perdus au milieu de tout cela, nous nous regardions, nous étions seuls au monde, isolés, définitivement ailleurs $(2005,100)$.

Accordingly, emphasising his belief in social determinism, the environments Adam describes reflect the moods of his characters: small, muddy gardens on housing estates leading to alienation and depression: ‘le jardin semble si désolé, si petit’ (2001, 21). While this concrete listing of objects, tastes and appearances links the world of the book clearly to the social world and to a specific time and place, it can also be seen, Perec-style, as a vain attempt to capture the world in language, this potential failure rather in keeping with Adam’s alienated characters.

While this quasi-documentary style became Adam's calling card, it was in his ninth novel, Les lisières (Flammarion, 2012) ${ }^{16}$, that Adam finally laid bare the issues that have haunted his work since he published his first novel Je vais bien, ne t'en fais pas, in 2001 with small

${ }^{16}$ The title itself testifies to Adam's continuing interest in what is sidelined. 
publisher Le Dillettante. ${ }^{17}$ Les lisières, which charts Paul Steiner’s return from Brittany, to where he has escaped with his family, to the Parisian banlieue in which he grew up, is a repetitive, angry, raw, semi-autobiographical novel expressing Adam’s disaffection with his family, his class, French contemporary society, and the literary scene. Paul Steiner accuses the publishing world of elitism and small-mindedness. He objects to the narrowness of both the type of character and the geography represented, to what he sees as the eschewal of both 'les classes moyenne et populaire’ and 'la province, les zones périurbaines...' (2012, 452)

Le Magazine Littéraire calls the France he describes ‘périphérique’ (Perrier 2016, 66).

However, Adam's creative work repeatedly puts it at its centre, insisting both in and outside his novels that the suburban working-classes in fact constitute the majority of the French population, yet that they do not commonly feature in contemporary French literature, describing 'un paysage littéraire français marqué par la désertion du majoritaire, du commun, du « social »...' (Adam 2013). Further, Adam claims that those like himself, who do treat working-class lives, have their work described as 'populiste, manichéiste’ (2013). ${ }^{18}$ Just after Les lisières was published, Adam laid out his writing manifesto in an incendiary article which appeared in Le Nouvel Observateur. In it, Adam condemns the contemporary French novel for its lack of a sense of social determinism:

Tout s’y passe comme si le poids du déterminisme, des luttes et conflits de classe, les questions liées au travail, au logement, à la précarité, au manque d’argent, à la ségrégation sociale et géographique, etc. .... n’avait aucune répercussion sur la psyché, les affects, les manières d’être, de penser, de se construire. Comme si tout cela constituait un ensemble de données moins

\footnotetext{
${ }^{17}$ His second novel, A l'Ouest, was published with L'Olivier, an off-shoot of Seuil, with whom Adam stayed until 2012, when he followed his editor, Alix Penent, to Flammarion.

${ }^{18}$ See for example Philippe 2012, in which Adam is described as 'pleurnichard et complaisant...' or Béglé 2005, in which the reviewer describes 'la noirceur qu’Olivier Adam se plaît à badigeonner sans modération'
} 
pertinentes que, par exemple, le facteur «psychologique». Comme si l'on pouvait d'ailleurs scinder à l'intérieur des êtres ce qui relève de l'individuel et ce qui a trait au social (Adam 2013).

The coherence between the ideas expressed in Les lisières and Adam's Nouvel Observateur article demonstrates the clear political position of Adam's literary work.

In Les lisières, Paul Steiner, also a writer, points out that he is referred to as '[un auteur] social' as a result of his preoccupation with society and with the 'classes populaires', recalling the point made earlier about genre fiction, and suggesting that the label 'author' without a qualifier now belongs to a certain subject, theme or style (Adam 2012, 406-7, 452).

\section{Edouard Louis and books as violence}

Edouard Louis has been equally outspoken in his criticism of the French literary scene and its treatment of issues of social class. Louis is remarkable in part for his extreme youth: his first novel, En finir avec Eddy Bellegueule, was published when he was 22 years old; however, he is also somewhat infamous as a result of its subject matter - the physical and psychological violence associated with growing up in poverty and facing homophobia in a small, workingclass, northern French community - and the scandal evoked in the media by the tracing of its autobiographical 'truth'. ${ }^{19}$ Indeed interest in Louis and his story spilled out of the literature pages and reviews to be discussed on primetime TV and in articles on the role of the author (Birnbaum 2014). While the autobiographical attention Edouard Louis's novel received was seen by some to be unseemly, it is known that Louis himself is a class defector, ${ }^{20}$ and has, in the words of Télérama: 'passé du sous-prolétariat à l'Ecole normale supérieure [...]' (Abescat 2014), Eddy Bellegueule was one of the ‘événements littéraires’ of 2013: it was nominated for a bevy of literary prizes, was widely translated and made into a film by André Téchiné:

\footnotetext{
19 The front cover of Eddy is labelled 'roman'.

20 The French term 'transfuge' is used widely in the media.
} 
Quand on a 17 ans. Louis's second novel, Histoire de la violence (Seuil), was published in 2016. However, Louis, a devotee of Pierre Bourdieu, had previously edited a collection of essays entitled Pierre Bourdieu: L'insoumission en heritage (PUF, 2013), already revealing an interest in the links between class, society and literature.

In Eddy Bellegueule Louis describes a milieu poorer and more desperate than that portrayed by Olivier Adam. While boredom and cultural apathy are the principal levers of unhappiness for Adam's characters, Louis’s Eddy also has to deal with crushing poverty, the corollaries of which include hunger, dirt and illness. Indeed, the narrator talks about the men's bad backs due to debilitating factory work and the women's problems with their fingers joints and wrists as a result of 'la maladie des caissières' (Louis 2014, 37-8). Recalling the referential specificity and social determinism of Adam's world, Eddy describes his uncle’s descent into bad health as a result of 'la violence de classe':

le tabac jaunissait ses dents, plus noires que jaunes, l’odeur des Gitanes imprégnait ses vêtements. Il avait fumé mais aussi beaucoup bu après le travail, comme mon père, pour oublier ses journées harassantes à porter des cartons, des colis, à manger en quinze minutes montre en main un mauvais repas réchauffé, préparé la veille par sa femme et déposé dans sa gamelle. Le bruit du centre de tri, assourdissant, agressif même. À peine le temps de s’asseoir pour déjeuner et le rappel oppressant du chef de chaîne s'il dépassait d'une minute le temps de sa pause $(2014,115)$.

Drawing on Bourdieu, Louis describes the moment when Eddy's cousin faces a court hearing and does not understand the questions he is asked as 'cette violence de classe':

D’autres questions qu'il ne comprenait pas à cause du langage, pas seulement de l'institution judiciaire, mais des mondes où les individus font des études...cette 
violence de classe qui l'avait exclu du monde scolaire et, finalement, par une série de causes et d'effets, cette violence qui l'avait mené jusque-là, au tribunal $(2014,129)$.

But Eddy tells us that he imagines his cousin would not have been embarrassed by his ignorance and confusion in the face of his trial, would not be aware of the 'violence de classe', but that he would rather think that the prosecutor 'parlait comme un pédé.' (2014, 129) Indeed the physical violence that Eddy himself suffers in his community is always as a result of homophobia. Significantly, Louis brings together what he perceives as workingclass behaviour and the masculine signalling of heterosexuality, including 'se promener nu dans la maison, les rots à table, les mains qui n'étaient pas lavées avant le repas’ (2014, 1745). On encountering the 'façons délicates' $(2014,201)$ of the bourgeoisie when he arrives at college in Amiens, Eddy begins to blame his long-held sense of difference from those he grew up around on class rather than sexuality: 'Je ne suis peut-être pas pédé, pas comme je l'ai pensé, peut-être ai-je depuis toujours un corps de bourgeois prisonnier du monde de mon enfance' $(2014,202)$. While Louis thus has Eddy bring these aspects of his identity into conflict, sociologist Didier Eribon’s bestselling memoir Retour à Reims (2010) points towards the silence and shame surrounding the working-class experience by posing the question: ‘Pourquoi moi qui ai tant écrit sur les mécanismes de la domination, n’ai-je jamais écrit sur la domination sociale ?' (Eribon 2010, 21). Indeed while Eribon has written extensively on what he calls 'la honte sexuelle', Retour à Reims is in part a first attempt to come to terms with his own working-class origins, or, as he puts it, 'la honte sociale' (2010, 21).

In an interview for The Guardian, Louis tells of the violence of a system which rejects those who do not share bourgeois values: 'Culture, the education system, books had all given us a feeling of rejection: in return, we rejected them. If culture paid us no attention, we would have our revenge. We despised it’ (Louis 2017b). In fact, Louis's revenge is to rehabilitate 
the working-class society he grew up in and turn it into literature. Beyond the simple inclusion of content rarely seen in literary fiction, Louis's style at times renders that content poetic. His use of chapter titles, for example, in Eddy Bellegueule, functions to break the linear flow of the chronological and introduce poignant snapshots, such as: 'Portrait de ma mère au matin', and 'La chambre de mes parents', belying the grinding poverty he will go on to describe. ${ }^{21}$ For Louis, the very inclusion of a world which is not considered 'literary' is thus simultaneously an act of literature and a political act (Farsethås 2016). ${ }^{22}$

\section{Conclusion}

On a contemporary literary scene which tends to treat social realism and the relationship between literature and politics with suspicion, the work of Olivier Adam and Edouard Louis stands out. They do not follow the aesthetic norms which apparently make literary fiction universally resonant, nor do they shy away from a clear expression of political conviction. While the link between the world and the text in their novels is fairly unproblematic, in both cases their work also clearly functions as a howl of protest against inadequate literary education and exclusion, and as a metatextual critique of the literary scene.

Olivier Adam demands that we confront the forgotten working-class of the banlieue and insists on the role of the social in the contemporary novel; Edouard Louis shows us a working-class abandoned by, and hostile to, literary culture. Together these writers critique the French literary scene, which arguably represents a world limited by not only the social background of writers, but also the perceived function of literature.

In En finir avec Eddy Bellegueule, Louis does not recount the other side of Eddy's transformation - the difficulties he inevitably encountered when it came to being accepted by

\footnotetext{
${ }^{21}$ It should be noted here that some reviews criticised Louis for what has been read as a humiliating portrayal of his family and his background. See, for example, Meizoz 2014 and Willems 2014.

${ }^{22}$ See also Laurin 2014.
} 
the middle-classes - however, outside his creative work, he has commented on feeling like an outsider each time he had to record his parents’ occupations (Abescat). Yet, as Olivier Adam perhaps anticipates, Louis would have to enter the literary scene to suffer fully the prejudice linked to his class defection:

Ce que j’ai senti dans ce qui n'est quand même qu'une toute petite partie de la réception du livre heureusement, c’est une certaine haine du transfuge de classe. Celui qui vient d’un milieu d’où ne viennent pas habituellement les écrivains suscite en effet un soupçon d'imposture ou je ne sais quoi d'autre. Quelque chose m’a stupéfait par exemple, c’est que plus le livre rencontrait d’écho et plus les journalistes m’appelaient Eddy, comme un effort acharné pour me remettre à ma place (Lalanne 2014).

While the work of both Adam and Louis is successful, ${ }^{23}$ they clearly feel that their literary journey has been, and continues to be, a struggle, and their identity as writers, an exception. That they are outspoken about this, and about the problematic relationship between literature and the social in the Francophone world, makes them relatively unusual. They are also notable for having avoided the various forms of genre fiction in which the working-class experience finds itself packaged, fitting neatly, for example, into neither 'littérature de banlieue', nor 'fiction d'affaires', despite sharing some of their themes. If the working-class experience has largely been relegated to genre fiction, it follows that contemporary literary fiction is not about work, for example, and not about la banlieue, to take the two categories mentioned above.

That Olivier Adam is 'un auteur social' and Edouard Louis is, to the French literary world, simply 'Eddy', are symptoms of a system in which contemporary literary fiction is commonly

\footnotetext{
${ }^{23}$ Apparently Adam’s books sell around 70,000 copies on first release. See Cohen 2011, 19. Louis’s first novel sold over 160,000 copies. See 'En finir avec Eddy Bellegueule et renaître un bestseller' 2014.
} 
perceived to be universal, but is in fact remarkably specific. In demanding what is perceived to be universality, but which in fact represents the interests of the middle classes, and bolstered by a strong intellectual scepticism of the unproblematic relationship between literature and the world, the French literary scene is effectively excluding the social experience of large swathes of the population. We are seeing the production of a literature which excludes 'otherness', or alternatively packages it carefully as 'la fiction d'affaires' or 'la littérature de banlieue’. Naturally, fear of the uncomfortable social message propagated by authors such as Adam and Louis contributes to this desire to sideline and control, but so does an idealistic approach to literature. Bourdieu showed that the desire for literature to be universal is impossible: that literature is always and already dependent on external considerations. Indeed, the sense that literature is, or can be, unaffected by social and political considerations is perhaps only to be enjoyed by those who are safely ensconced within the system. As Bourdieu made plain, social domination leads to cultural domination, and vice versa. While there is clearly awareness in the French literary world of the potential for misrepresentation, as seen by the littérature monde campaign, there is much more to do. Edouard Louis’s Eddy emphasises the educational disadvantage of the working-class world he describes:

Tandis que je passais du temps à l'arrêt de bus, d'autres enfants comme elle, Amélie, lisaient des livres offerts par leurs parents, allaient au cinéma, et même au théâtre. Leurs parents parlaient de littérature le soir, d’histoire - une conversation sur Aliénor d’Aquitaine entre Amélie et sa mère m’avait fait pâlir de honte -, quand ils dînaient. (2014, 99).

Perhaps part of the remedy for the perpetual cycle of poverty and failing education Louis describes is the renewed visibility of working-class people in literature, as well as the 
acceptance that the value placed upon the aesthetic has, to some extent, sidelined the working-class novel, and thus the representation of the daily experience of many citizens.

\section{Bibliography}

Abescat, Michel. 2014. 'Edouard Louis : 'J'ai pris de plein fouet la haine du transfuge de classe’, Télérama, 15 July 2014, http://www.telerama.fr/livre/edouard-louis-j-ai-pris-deplein-fouet-la-haine-du-transfuge-de-classe,114981.php

Adam, Olivier. 2001. À l’Ouest, Paris : Editions de l’Olivier

Adam, Olivier. 2005. Falaises, Paris : Editions de l’Olivier

Adam, Olivier. 2012. Les lisières, Paris : Flammarion

Adam, Olivier. 2013. 'Pourquoi les romanciers français devraient lire Bourdieu', BibliObs, 6 mars 2013, http://bibliobs.nouvelobs.com/essais/20130131.OBS7417/pourquoi-lesromanciers-francais-devraient-lire-bourdieu.html

Asholt, Wolfgang. 2002. 'Deux retours au réalisme? Les récits de François Bon et les romans de Michel Houellebecq et de Frédéric Beigbeider’, Lendemains, vol. 27, www.tierslivre.net/univ/X2000_WAsholt_Real.pdf

Asholt, Wolfgang and Marc Dambre. 2011. 'Avant-propos', in Wolfgang Asholt and Marc Dambre (eds), Un retour des normes romanesques dans la littérature française contemporaine, Paris : Presses Sorbonne Nouvelle, 11-17

Barthes, Roland. [1953] 1972. « L’écriture et la parole », in Roland Barthes, Le degré zéro de la littérature suivi de Nouveaux essais critiques, Paris : Seuil

Béglé, Jérôme. 2005. 'La vie en noir d’Olivier Adam’, Paris Match, 16 novembre 2005, http://www.parismatch.com/Culture/Livres/La-vie-en-noir-d-Olivier-Adam-135204

Beinstingel, Thierry. 2012. 'Langages et littératures du travail chez les écrivains français depuis mai 1968’, Intercâmbio, 5, 50-60

Birnbaum, Jean. 2014. L'éditorial du Monde des Livres, 'Edouard Louis dit les choses', 13 March 2014, http://www.lemonde.fr/livres/article/2014/03/13/edouard-louis-dit-leschoses_4382155_3260.html

Bourdieu, Pierre. 1979. La distinction: critique sociale du jugement, Paris: Minuit

Bourdieu, Pierre. 1992. 'Il faut que l'intellectuel donne la parole 'a ceux qui ne l'ont pas !', L’Evénement du jeudi, 10-16 septembre 1992, propos recueillis par Philippe Petit, 114-6

Busnel, François. 2012. 'Olivier Adam : on se ment beaucoup à soi-même', L'Express, 28 août 2012, http://www.lexpress.fr/culture/livre/olivier-adam-on-se-ment-beaucoup-a-soimeme_1153041.html 
Caramaschi, Enzo. 1971. Réalisme et impressionisme dans l'œuvre des frères Goncourt, Paris: Nizet

Castel, Robert. 1995. Les Métamorphoses de la question sociale, Paris : Fayard

Chadderton, Helena. 2017a. 'The littérature mineure of François Bon', Studies in $20^{\text {th }} \& 21^{\text {st }}$ Century Literature, 41:1, https://doi.org/10.4148/2334-4415.1870

Chadderton, Helena. 2017b. 'Engagement in la fiction d'affaires: François Bon and Thierry Beinstingel', in Engagement in French and Francophone Culture : Countering Crises, edited by Chadderton, Helena and Kimyongür, Angela, Cardiff : UWP, 13-25

Chadderton, Helena and Angela Kimyongür, eds. 2017. Engagement in French and Francophone Culture : Countering Crises, Cardiff : UWP

Coetzee, J.M. 1999. Disgrace, London: Vintage

Cloonan, William. 2008. 'Fiction in the Fifth: the Novel in the Fifth Republic', Contemporary French and Francophone Studies, 12.2, 277-84

Cohen, Olivier. 2011. 'Créativité et/ou solidité: le long chemin d'une maison d’édition', Le Journal de l'Ecole de Paris du Management, 5/91, 17-22

Daeninckx, Didier. 1997. 'Entretien avec Robert Deleuse’, Ecrire en contre, PUF

Davis, Colin and Elizabeth Fallaize. 2000. French Fiction in the Mitterrand Years: Memory, Narrative, Desire, Oxford University Press: Oxford Studies in European Culture

Domenach, Jean-Marie. 1995. Crépuscule de la culture française? Paris: Plon

Dumas, Maryse. 2002. 'Postface’ in Sophie Béroud and Tania Régin (eds), Le roman social. Littérature, histoire et mouvement social, Paris : Led éditions de l'atélier et éditions ouvrières

Eribon, Didier. 2010. Retour à Reims, Paris: Flammarion, Champs Essais

Ernaux, Annie. 1974. Les armoires vides, Paris : Gallimard

Farsethås, Ane. 2016. 'The State of the Political Novel: an Interview with Edouard Louis', The Paris Review, May 3 ${ }^{\text {rd }}$, 2016, https://www.theparisreview.org/blog/2016/05/03/the-stateof-the-political-novel-an-interview-with-edouard-louis/

Filipetti, Aurélie. 2003. Les derniers jours de la classe ouvrière, Paris : Stock

Gefen, Alexandre. 2010. 'Réalisme de François Bon', in François Bon, éclats de réalité, edited by Dominique Viart and Jean-Bernard Vray, PU de St Étienne, 93-101

Giocanti, Stéphane. 2009. Une histoire politique de la littérature, Paris: Flammarion

Hargreaves, Alec G. 2014. 'De la littérature « beur » à la littérature de «banlieue » : des écrivains en quête de reconnaissance’, Africultures, no. 97, 144-49 
Hargreaves, Alec G. 2013. 'Banlieue blues', in The Cambridge Companion to the Literature of Paris, edited by Anna-Louise Milne, Cambridge : Cambridge University Press, 212-27

Hynyen, Andrea. 2017. ‘Crime and Comedy: Dominique Sylvain’s Ingrid Diesel and Lola Jost Series Post 9/11', in Engagement in French and Francophone Culture : Countering Crises, edited by Chadderton, Helena and Kimyongür, Angela, Cardiff : UWP, 127-149

Jourde, Pierre. 2002. La littérature sans estomac, Paris : L’Esprit des Peninsules

Kemp, Simon. 2010. French Fiction into the Twenty-first Century: The Return to the Story, Cardiff: UWP

Lalanne, Jean-Marc. 2014. 'Homophobie, violence, enfance : Xavier Dolan et Edouard Louis se parlent', Les Inrocks, 7 May 2014,

http://www.lesinrocks.com/2014/05/07/cinema/homophobie-violence-enfance-xavier-dolan$\underline{11502753 /}$

Laurin, Danielle. 2014. 'Edouard Louis : fuir pour se réinventer', Le Devoir, 26 April 2014, http://www.ledevoir.com/culture/livres/406467/edouard-louis-fuir-pour-se-reinventer

Le Breton, Mireille. 2013. 'De la littérature beur à la littérature de banlieue : un changement de paradigme’, Présence Francophone, no.80, 12-26

Le Bris, Michel and Jean Rouaud, eds. 2007a. Pour une littérature-monde, Paris: Gallimard Le Bris, Michel and Jean Rouaud et al. 2007b. 'Pour une littérature-monde en français', Le Monde des Livres, 16 March 2007, 2

Louis, Edouard. 2013. Pierre Bourdieu: L’insoumission en heritage, Paris : PUF

Louis, Edouard. 2014. En finir avec Eddy Bellegueule, Paris : Seuil

Louis, Edouard. 2016. Histoire de la violence, Paris : Seuil

Louis, Edouard. 2017a. 'First person : 'I wanted my family to know I wasn’t like them. A book was the most violent instrument I could use.' The Guardian Review, 11 February 2017, 12

Louis, Edouard. 2017b. 'Edouard Louis: For my family, a book was a kind of assault', The Guardian, 11 February 2017, https://www.theguardian.com/books/2017/feb/11/edouardlouis-books-assult-elite-working-classes-culture

Macé-Scaron, Joseph. 2012. 'L'oeuvre au noir', Le Magazine Littéraire, May 2012, 3

Magloire, Frank. 2012. Ouvrière, Paris : Points

Mandelbaum, Jacques. 2007. ' J'ai très mal au travail: décadence en entreprise', Le Monde, 30 October 2007, http://www.lemonde.fr/cinema/article/2007/10/30/j-ai-tres-mal-au-travaildecadence-en-entreprise_972580_3476.html 
Dominique Manotti in conversation with Angela Kimyongür. 2014. Unpublished interview, '21 $1^{\text {st }}$ Century Engagements: Countering Crises', conference, 17 September 2014.

Martin, Jean-Pierre. 2010. ‘Avant-propos’, in Bourdieu et la littérature, edied by Jean-Pierre Martin, Nantes : Editions Cécile Defaut, 7-21

Meizoz, Jérôme. 2014. 'Belle gueule d’Edouard ou dégoût de classe ?’, COnTEXTES, Prises de position, 10 March 2014, http://journals.openedition.org/contextes/5879

Not, André and Jérôme Radwan. 2003. Autour d'Henry Poulaille et de la littérature prolétarienne, Aix-en-Provence : Publications de l’Université de Provence

Perrier, Jean-Claude. 2016. 'Olivier Adam, Romancier « à ras d'homme »', Le Magazine Littéraire, 564, February 2016, 66-7

Philippe, Elisabeth. 2012. 'L'arnaque Florian Zeller et Olivier Adam, écrivains en toc', Les Inrocks, 2 septembre 2012, http://www.lesinrocks.com/2012/09/02/livres/arnaque-florianzeller-olivier-adam-11292295/

Pobel, Céline. 2003. 'Nouvel Âge Littéraire (bis) ou quand le peuple persiste et signe "Beur »', in Autour de Henry Poulaille et de la littérature prolétarienne, edited by André Not and Jérôme Radwan, Aix-en-Provence : Publications de l’Université de Provence, 203221

Ragon, Michel. [1974] 1986, Histoire de la littérature prolétarienne de langue française, Paris : Albin Michel

Raynal, David. 2014. 'Olivier Adam, des lisières de la ville à celle de la Bretagne’, Bretagne Actuelle, 12 July 2014, http://www.bretagne-actuelle.com/olivier-adam-des-lisieres-de-laville-a-celle-de-la-bretagne/livres/roman/434-1-26.

Rubino, Gianfranco. 2010. 'Espace(s)' in François Bon, éclats de réalité, edited by Dominique Viart and Jean-Bernard Vray, PU de St Étienne, 105-14

Sapiro, Gisèle. 2003. 'Forms of politicization in the French literary field', Theory and society, 32, 633-52

Sepausy, Victor de. 2014. 'Goncourt : Carrère et Olivier Adam absents de la première sélection’, ActuaLitté, 5 septembre 2014, https://www.actualitte.com/article/culture-artslettres/goncourt-carrere-et-olivier-adam-absents-de-la-premiere-selection/51089.

Todorov, Tzvetan. 2007. La littérature en péril, Paris : Flammarion, 2007

Touraine, Alain. 1992. Critique de la modernité, Paris : Fayard

Tremblay-Cléroux, Marie-Ève. 2014. 'Porosité des frontières sociales et politiques dans Les lisières d’Olivier Adam’, Postures, 20, 35-48 
Viart, Dominique. 2007. 'Littérature et sociologie, les champs du dialogue' in Littérature et sociologie, edited by Philippe Baudorre, Dominique Rabaté, Dominique Viart, Bordeaux : Presses Universitaires de Bordeaux, 11- 28

Viart, Dominique and Bruno Vercier. 2005. La littérature au présent : Héritage, Modernité, Mutations, Paris : Bordas

Walker, David H. 1997. 'Formal experiment and innovation', in The Cambridge Companion to The French Novel, from 1800 to the present, edited by Timothy Unwin, Cambridge University Press, 126-44

Waller, Roselyne. 2010. “ « La mine comme horizon magique » : Les Derniers Jours de la classe ouvrière (Aurélie Filipetti)' in Les Formes du Politique, edited by Corinne Grenouillet and Eléonore Reverzy, Strasbourg: Presses Universitaires de Strasbourg

Willems, Thibaut. 2014. ' « Eddy Belleguele »: suis-je le seul à être choqué ?’ Le Nouvel Observateur, 16 February 2014, https://www.nouvelobs.com/rue89/rue89-rue89culture/20140216.RUE2086/eddy-bellegueule-suis-je-le-seul-a-etre-choque.html

Wolf, Laurent. 2006. 'Le roman, la politique et la périphérie', Le Temps, 4 February 2006 Wolf, Nelly. 1990. Le peuple dans le roman français de Zola à Céline, Paris : PUF 